\title{
The Research Overview of Western Political Circles on China's Political Ecology
}

\author{
Yunzhe Chen ${ }^{1,2}$ \\ ${ }^{1}$ Australia University of New South Wales, Australia \\ ${ }^{2}$ League Institute for Theoretical Work, China Youth University for Political Sciences (The Central Communist \\ Youth League), China \\ Correspondence: Yunzhe Chen, School of Humanity and Social Science, Building 28, University of New South \\ Wales (Canberra), Canberra, Australia. Tel: 6-126-268-8867. E-mail: Yunzhe.chen@student.adfa.edu.au
}

Received: April 29, 2014 Accepted: May 19, 2014 Online Published: May 28, 2014

doi:10.5539/jpl.v7n2p41 URL: http://dx.doi.org/10.5539/jpl.v7n2p41

\begin{abstract}
Due to the difference of political system and great achievements of the reform and opening up, China's political ecology has attracted more and more attention from scholars at home and abroad. In China, political theory researchers are keen on explaining problems of China through western political theory, while western political academic circles cannot develop a macroscopic theory explaining political ecology with Chinese characteristics because of the inherent mind-set. Therefore, this thesis teases out China's political literature research by the west since the founding of PRC, attributes the uniqueness of China's political ecology to four aspects which are "Authoritarian Resilience" and "Party Adaptation", a civilization of long standing and a sense of national identity, Confucian culture and the traditional centralized management as well as the response of type conversion of leader cadres to social needs. This thesis puts up some proposals on politics study of China in the future, and explains macroscopic theory of China phenomenon with Chinese discourse.
\end{abstract}

Keywords: China, political ecology, uniqueness

\section{Introduction}

Since the reform and opening up for more than 30 years, China has become the second largest economy in the world from a third world country on the brink of bankruptcy. At the same time, western society has trapped in financial crisis for several times, and its economic growth has stagnated for years. More and more western scholars begin to pay attention to China's political ecology (especially the development and change of the Chinese Communist Party) internationally and try to puzzle out the deep reasons of China miracle. But, as Martin Jacques pointed out at TED speech, people in western countries incline to understand Chinese society from their concept and cognition for politics and society which are based on their own historical and cultural traditions. In other words, they never understand Chinese problems with Chinese concept (Note 1). Therefore, the espoused theories are often full of mistakes and unable to predict China's future development accurately except particular phenomenon in short time. The viewpoint of Martin Jacques coincides with a number of political experts in China. In the current political research process of China, a large number of western scholars with objectives opinions hold that China's political system is different from the previous understanding of politics to political system and culture. There is no corresponding relatively accurate theory to understand Chinese politics.

As Michel Oksenberg, a well-known Chinese expert of the United States pointed: “..... such previous depictions as 'totalitarianism', a 'Leninist party state', 'fragmented authoritarianism', 'soft authoritarianism' or 'bureaucratic pluralism' miss the complexity of China's state structure” (Oksenberg, 2002).

Or Tang Tsou, a world-famous ethnic Chinese professor of University of Chicago stated: “....political development in twentieth-century China, particularly the history of the Chinese Communist Movement and regime, is so complex and unprecedented that no general model readily fits the Chinese case...." (Tang, 1986)

In this regard, the thesis will be the first to tease out the previous western literature and draw the developing track of China studies in the west from 1949 to 2012. Then, the thesis will put forward four reasons that cause 
the uniqueness of China's political ecology and some suggestions as well as ideas of China studies in the future through a comprehensive analysis of existing literature.

\section{Retrospect on Research Literature of China's Contemporary Political Ecology}

According to time sequence, the research of China's contemporary political ecology could be divided into four periods: early days of new China, 10 years of the Great Cultural Revolution of China, reform and opening-up as well as China in the future. All of them present different research characteristics.

During the research of early days of new China, because of the similarity and relevance between Chinese communist regime and the former Soviet Union, the analysis of the China's problems was mainly depending on Totalitarian Model (Arendt, 2004; Schapiro, 1972; Goldstein, 1994) which was derived from the Soviet Union. Overall, they thought Chinese communist regime and the Soviet Union (especially in Stalin's era) had the same general characteristics in four aspects: "Official Ideology", "Party-State", "Plan Economic", "Secret Police" and "Party Monopoly of Media and Army". In addition, the party's political elites were highly united around comrade Mao Zedong (Schurmann, 1966; Walker, 1955; Barnett, 1960; Lewis, 1963).

However, as the outbreak of Cultural Revolution, the understanding of western circle to China politics was completely changed. In the political community, western scholars began to suspect the unity inside the the party's political elites and consider the contradictions and differences always exist under the appearance of the unity. The "Factionalism Mode", presented by Professor Andrew Nathan firstly, was used for discovering the influence of "guanxi" in China politics. After the development and promotion by scholars such as Professor Tang Tsou and Professor Lowell Dittmer, the western studies on Chinese politics were expanded from "guanxi" to a broad field of Informal Politics. As to the causes for factions as well as struggle rules of factions, the scholars did not reach an agreement on them. For example, from the perspective of politics and culture, Lucian Pye held that the Chinese specific sense of insecurity is the cultural reason to form factions. Doctor Jing Huang thought the reason was "Shantou Politics", which derived from the base fight practice in early times of the Communist Party of China. In the aspect of struggle rules, Professor Andrew Nathan considered that factions followed certain principles of etiquette, leading to one of the factions would not extinct during struggle. However, Tang Tsou insisted that winner-take-all was the essence of the factional strife. The idea of Informal Politics influencing China's elite politics was accepted and incorporated into the corresponding reasons by western researchers.

At the same time, as the victims of cultural revolution, the older generation with comrade Deng Xiaoping as the representative of the proletarian revolutionists deeply realized the dangers of excessive concentration of power and personality cult as well as the defects of traditional socialist regime in the political succession and right enforcement, thus they started the great journey of reform and opening up, which was called by Professor Zheng Yongnian from National University of Singapore as "Socialism Reflection" (Note 2).

Many western scholars have summed up that the thirty years of reform and opening up is mainly limited in the economic field, which in the writer's opinion is biased. In fact, the political reform in China is also advancing and focusing on institutionalization. Generally speaking, after the Third Plenary Session of the 11th Central Committee of the Chinese Communist Party, China has achieved developments in politics as follows: firstly, the belligerence ideology of "taking class struggle as the key link" is significantly weakened, and the ruling party has become more pragmatic and attached great importance to the economic development; secondly, political succession and right enforcement show a trend of peace, institutionalization and echelon. This is far better than the bloody transition after Stalin in the former Soviet Union7. At present, the leadership types in China's politics have transformed into Bureaucratic Leadership from Heroic Leadership (Meyer, 1983). In addition, the source of authority has transited from individual leaders to body functions, realizing the sustainable development of real significance in politics.

In addition, many Chinese observers such as Professor Licheng and Professor Kou Jianwen from National Chengchi University found that there was "Politics Exit" arrangement and succession in echelon system. To be specific, the Communist Party of China completely abolished the traditional socialist regime institutional drawbacks of the lifelong official system through "Age Limitation" and "Tenure Limitation". The qualified socialist successors could be trained and selected according to "ladder of the leading cadre promotion through step by step". The general secretary is the core of the party, but instead of excessive concentration of power in an individual leader, the highest decision-making body system is transformed to the Politburo Standing Committee, individual responsibility and collective leadership, which prevents the birth of absolute power and ensures the efficiency, decisiveness and scientificity of decisions (Kou, 2010). This stands in sharp contrast to the constrain phenomenon between the current ruling party and the opposition party in the west. 
Thirdly, the participation way of political movement has been repudiated gradually, and the rational inner-party democracy construction and legal construction are in steady progress. In the socialism practice of Soviet Union, especially in Comrade Lenin' opinion, the law should be broken for being one of the tools of the exploitation by the bourgeois class. In Chinese society at that time, because of the need of social revolution, not only the legal norm was not paid enough attention to, moreover, the repressive measures which could quickly gathered social forces were pushed hard (e.g., the political participation of the movement type). The atrocity during Cultural Revolution was the prominent performance of the weak legal system consciousness in the whole society. However, with the foundation of new China, the new society needed healthy and sustainable development. The idea of "take the law as the criterion" should be put to the center position of the whole social construction.

In recent years, with the deepening of the legal system construction and promoting of democracy at the grassroots level, the previous rigid way of repression has been transformed into flexible governance in respect of Party discipline and national law. For example, the effective solution of Wukan Event (Note 4), in addition to demonstrate the significant progress of our party in the legal consciousness and management mode, also make a positive exploration to better solve the group events.

Fourthly, the government affairs are more public, and the ruling party is more modest and can accommodate more opinions. During the period of comrade Hu Jintao as general secretary, more and more critical comments from intellectuals can be spread in the public media and academic journals. The leading cadres of all levels of our party are more and more willing to participate in the discussion of public policy, and turn to experts for help when our nation facing predicament and difficulties. In short, even Professor Bruce Dickson (Dickson, 1997), who holds a pessimistic attitude to the future of socialism in China, cannot deny it. As Professor Huntington's prediction, the Communist Party of China has passed through the nascent stage and become a relatively stable political system through transformation, consolidation as well as adaptation (Huntington \& Moore, 1970).

What will be the future of China? The answer is very controversial in western circles at present. Professor David Shambaugh is the first scholar to analyze the Communist Party of China as an independent research object. According to his analysis and observation, our party is undergoing the atrophic and adaptive course of development. He describes the mainstream views of western circles for the Communist Party of China as well as the future of China in his important book China's Communist Party: atrophy and adaptation (Shambaugh, 2008).

Specifically, the scholars with pessimistic attitude believe that the Communist party of China will fall into a long-term stagnation. For example, Professor Susan Shirk, once served as assistant secretary of State, thinks the Communist party of China is actually a Fragile Superpower (Shirk, 2007) with a seemingly powerful surface and contradictory internal system which cannot be reconciled. Both Professor Richard from University of California and Professor Roderick MacFarquhar from Harvard University think that the Communist party of China are facing a series of crisis and difficulties which are unlikely to be solved and will cause the inevitable collapse of the whole regime (Note 5). Comparatively, Gordon Chang and Bruce Gilley are more acute and they directly predict that China will face collapse in a short term.

But, in the end, the collapse of the schedule from Gordon Chang's book The Coming Collapse of China reduced to be a laughing stock in western political circle. In addition to the pessimistic view of "short-term collapse", Professor Pei Minxin predicts in one of his books China's Trapped Transition: The Limits of Developmental Autocracy that China will not collapse instantly, nor democratize rapidly but fall into a Prolonged Stagnation (Pei, 2006). In contrast, there are many research scholars such as Professor Licheng, Yang Dali, Zheng Yongnian and David Shambaugh hold the optimistic attitude to the future of China. They generally believe the Communist party of China has a strong vitality proved by more than 30 years' practice of reform and opening up. It could overcome shortcomings and solve the current social problems. (Yang, 2003; Li, 2008; Zheng, 2011)

As Professor David Shambaugh points out, the controlling force of the Communist party of China over society is reduced dramatically. The main reasons leading to the reduction are due to the active reform of our party as well as the influence of globalization. However, the reduction of controlling froce does not mean the ruling status of the Party will be shaken; on the contrary, its ruling status will be stronger. In his view, the Communist Party of China is in a good development cycle, that is, "constant cycle of reform-readjust-reform-readjust..." Meantime, the party carries out reform gradually and adjusts it rationally to achieve sustainable development. The target of next stage of reform includes dealing with the problem emerged in the reform (Shambaugh, 2008). In view of the ruling party's outstanding performance in reform and opening up, recently, Professor Andrew Nathan has been constantly modifying his criticism proposed in early years and summed up his new experience and comprehension into "China's Resilient Authoritarianism" (Nathan, 2003). 
To western scholars, the Communist Party of China seems to overcome the defect of traditional socialist parties (e.g., the political succession, the abuse of power, etc.), and has not fallen into the constrained struggles for democracy (e.g., Japan and Australia). The Communist Party of China gradually forms a political system with Chinese characteristics in the centralized and decentralized power. There are considerable amount of literature has been aware of the uniqueness of Chinese political ecology, but hardly any of them to explore the reasons. Therefore, the writer will try to answer the question of "why China's ecology is so unique" through reviewing the previous western literature. Four reasons will be listed in the following sections, but it's not limited to the views in the thesis. The writer would like to start a discussion and explore the uniqueness of China's political ecology with political theorists.

\section{Cause Analysis of the Uniqueness of China's Political Ecology}

During the past research, scholars always hope to analyze and predict China phenomenon after putting it in certain theories(e.g., "Totalitarianism", "Authoritarianism", "Factionalism", "Political Generations" and "Technocrats", etc.) However, it's common that they cannot classify or only partial classify the problems. As the above two scholars' views: "the previous research theory ignore the complexity of state structure in China" and "China's development is extremely complex in 20th century without precedent, so there is no universal theory to explain the case in China".

First of all, as one of the last few socialist countries, China is aided by its political "authoritarian resilience" and "party adaptation", which are superior to those of former Soviet Union and Eastern Europe, to adapt to ever-changing social environment. To be specific, Andrew Nathan, a noted China hand in Columbia University, exposes us to the existence of the "authoritarian resilience" perceptually through analysing phenomena although he hasn't give an exact definition of Chinese "authoritarian resilience" . In his view, over 30 years of "institutionalization" has bred for Chinese Communist Party institutionalized political succession and power transition, elite ruling group, power restriction through institutional division as well as wide political input in order to maintain the governing legitimacy of Communist Party (Nathan, 2003) and give more resilience of regime to China than any other socialist countries. As to the "party adaptation", it is one of the core points insisted by Prof. David Shambaugh of the University of Washington. Among all expressions of the "party adaptation", transferring to absorb private entrepreneurs into Chinese Communist Party is one of the most significant. It is rightly this kind of "authoritarian resilience" along with the "party adaptation" that helps Chinese Communist Party to correct mistakes of the Cultural Revolution smoothly, regain support and trust from the public, as well as welcome the rapid economic growth consecutively and cope effectively with periodic financial crisis through the introduction of market economy system. The Chinese Communist Party is still tightly taking the helm of the state in spite of worsening wealth gap, institutional corruption, high unemployment, frequent mass disturbances, deteriorating environmental pollution and short supply of public goods (e.g. education and health care) (Pei, 2006; Shirk, 2007)

Secondly, there exists incomparable culture and sense of national identity (which is originated from the glorious national history extending over 5,000 years as well as Chinese firm belief of blood tie complex) (Pye, 1968), which is distinct from all other ex-colonies. Since the industrial revolution, western countries had begun their colonial aggression towards others all over the world. America, Africa and Asia fell into colonies consecutively. China was also colonized from a feudal society to be a semi-colonial and semi-feudal society after the First Opium War (1984). As a result, the starting point of China towards modernization is, just like those non-western countries, a colonial basis of which the traditional society collapsed. However, what makes China different from many countries of the world (such as Japan, Africa and America), lies in the following two aspects: China didn't accept the modern western regime thoroughly, and chose an independent development way rather than large-scale racial doubt and discard of national personality and identity (Pye, 1968). Furthermore, for political doctrines, only those political elites who can localize the doctrine (in other words, combine modern political doctrine with the Chinese traditional culture and its national conditions) could win the dominant right and public support. This also reflects Chinese politics and culture which tell China from other former colonies. For example, why was Leninism so popular in China during the 20th century? Brantley Womack, a well-known sinologist, holds that the reason is the similarity between Lenin ideology and traditional Confucianism, which enables the former to serve as a modern Chinese traditional outlook of revolution (Womack, 1991). Mao Zedong Thought and Deng Xiaoping Theory are reputed as two leaps of Marxism sinicization. However, revolutionary practices including "base construction", "guerrilla warfare", and "strategy of encircling the cities from the rural areas" of the former are also based on the inheritance of traditional peasant uprising, especially ancient history of war. The combination of "market economy system" and "socialist political regime" proposed by the latter is of much Chinese pragmatic meaning of "a black plum is as sweet as a white". 
Thirdly, traditional Chinese society is bred in a kind of absorptive but centralized soil due to time-honored influence imposed by Confucian culture and long-term tradition of centralized rule. To be specific, as to the social management, according to Prof. Zou Dang, although traditional Chinese feudal society was highly centralized ruled, the government system didn't monopolize the social management. The institution setting extended only to the level of county, while a level called "scholar-bureaucrat-landlord" (all called "gentry level") existed between the government and common people to assist the governmental management upon the mass. This kind of incomplete power monopoly structure not only maintained the central unity, but also left autonomous right to local management, which gifted certain "resilience" to the entire dictatorship. On one hand, without this adjustment-available autonomous right, it's hard for a central policy to satisfy Chinese society featured by huge regional and national difference. On the other hand, the limited regional autonomous right restrained the development space of local force effectively and avoided its growing tendency to be a threat against the central authority (Tang, 1986). From the nature of this "scholar-bureaucrat-landlord", it served as the bridge and ties between the ruling class and the ruled class, which aided the government to govern the mass and transferred the demand of the mass up to the government. This time-honored governance is probably the historical source of the CCP's management approach, namely, relying on the public organization to participate in the management of public affairs. Concerning the replacement of political elite, compared to other feudal countries, China before 1949 was relatively more open. The comparatively mature recommendation system (Fairbank, 1979) and imperial examination system (Bol, 1992), which occurred in Han Dynasty (206BC-220AD), reformed in Tang Dynasty (618AD-907AD) and prospered in Song Dynasty (960AD-1279AD), served to select talents for the government. Although blood linkage still worked as one of the vital criterions to distinguish nobles, common people were able to upgrade to be the ruling class through those two approaches above. Compared to the harsh and single standard of blood linkage in western countries, the traditional society of China appeared to be more open and lively. It was also the smooth access that enables countless talented statesmen from the populace could contribute prominently to the development of traditional China and promote the development of history.

Fourthly, looking back upon the development history of CPC in past 90 years, we could find the transformation of the CPC leadership types has responded sensitively to social demand. Although national leadership elections of China has always been different from American popular votes, which is featured by referendum, the replacement of the CPC leadership type could cater to social demand at that time more than that of democratic countries. As to this, Zhang Weiwei, a Chinese scholar who has insisted on Chinese model all the time once published an article Meritocracy vs. Democracy on New York Times at the moment of political transition in both China and America, the first and second biggest economic entities in 2012. His article states the superiority of China in the field of political inheritance and leadership selection (Note 6). The western circle (represented by Prof. Li Cheng of the Chinese Research Center of Brookings Institution) holds the elite leaders of CPC has grown through two phrases of revolutionary cadre (Li \& White, 1988) and technology bureaucracy (Li \& White, 1998(b); Zang, 1993) and is progressing towards diversified elite structure era. In this regard, on the breakdown of old Chinese society (before 1949) and faced with fierce foreign invasions, revolutionary cadre (Lee, 1983) (propagandists of theory, militarist and leaders of national movement) had already been proved to be the leadership type which could best adapt to the execution of social revolution and struggle of national independence. As the establishment of new China (in 1949), especially after the Third Plenary Session, revolutionary cadre has been replaced gradually by technocrat along with the deepening of Cadre Four Modernization (Note 7) (The contingent of cadres should become more revolutionary, better-educated, professionally, more competent and younger in age) (Li, 2001; Zang, 2004) (Note 8). They promoted the surge of China's industrialization and economic boost through their professional quality, which attracted worldwide attention. Now, on the enlarging of wealth gap and frequent occurrence of mass disturbance, a large quantity of cadres grown from Communist Youth League, who are regarded by western observers as followers of social fairness and justice have entered the center of Chinese political stage (Li, 2009; Li, 2005). In the meanwhile, as the increasing differentiation of social demand of China, cadres of high education and diversified subject background from various fields have flowed into leader teams of various levels.

In a word, the current political regime of China is so extremely complex that it could not be classified into any category. At present, no general theory in the circle of politics in the world expounds the China issue, just as Michel Oksenberg points:

“...... the core system is not entirely Leninist- Soviet in origin. Some aspects-such as the mobilization system, the nature of Party-army relations and the fusion of Party and government-can be traced to Yan'an and the guerrilla past. Other parts of the bureaucracy reflect a deeper imperial heritage, such 
as the revenue system, the method of classifying documents and the influence of Chinese cosmology. Yet other parts of the institutional arrangements derive from the Republican Kuomintang era, such as the Chinese People's Political Consultative Conference, the Party's United Front policy and the location of the State Copyright Administration inside the State Press and Publications Administration. Some other agencies continue to bear the imprint of their Western, especially American, origins such as the Ministry of Public Health and the Ministry of Education......" (Oksenberg, 2002)

\section{Outlook on China's Political Ecology}

Although there is no general theory could define the phenomenon of Chinese politics exactly, the research of Chinese politics has been in the phrase of theory packing and the academic understanding of Chinese policy is also deepening. Three suggestions about China studies in the future have been proposed by Lowell Dittmer, director of China Studies Centre of University of California along with Dr. William Hurst of Oxford University: devoting to middle-range analysis, attaching emphasis on quantitative analysis and further exploring the organizations remain unstudied (Dittmer and Liu). The first one concerns the study scale and focuses on advising scholars of China study to conduct systematic analysis of certain phenomenon and institutes, rather than explore the entire issue of Chinese politics generally. The second one indicates directly that quantitative analysis should be employed favourably in the study of politics. During the past study of Chinese politics, official documents, historical documents and uncertain information achieved from Hong Kong, Taiwan, etc. was more applied by western scholars to probe into Chinese issue due to the lack of information transparency. With widespread transparency of government affairs as well as relaxing academic atmosphere, the data kept as secret in the past (such as personal details of leaders at all levels) is easily accessible now. In the academic circle, a large quantity of sample survey reports in large scale as well as literature exploring sensitive subjects (just like the doctoral dissertation Cadres of Zhong County finished by Dr. Feng Junqi of Peking University) surge in Chinese academic circle. The last piece directs the exploration of unstudied institute and organizations. In the study of politics, which important organizations on earth have not attracted adequate attention? It demands a retrospect at the issues occurred during the study of Chinese politics in the past to discover those institutes and organizations in related fields.

According to the summary of Michel Oksenberg, the entire Chinese society could be classified to be three types of organizations and institutes, namely, "core apparatus", "linage intermediary institutions" as well as "legal, semi-legal and illegal organizations and associations" (Oksenberg, 2002). "Core apparatus" mainly covers the system of CPC and government. "Linage or intermediary institutions" refer to civil associations acknowledged officially by CPC (e.g., Labour Union, Women's Federation and the Communist Youth League). "Legal, semi-legal and illegal organizations and associations" consist mainly of numerous non-public enterprises and NGOs, containing all other types of organizations in China. Among current studies, western probe into "core apparatus" and "other types of organizations and associations" are the most, while the exploration of "linage or intermediary institutions" is relatively weak, with the latter mechanically borrows the corporatism to expound the CPC's management approach of the society via NGOs. As to the cause, the writer personally relates it to the study motive and the insufficient recognition of China's political ecology. Knowledge of the vital status of CPC in the whole China's political ecology makes it easy for us to understand the enthusiasm of scholars who are keen on "what the nature of China's political ecology is" to study the "core apparatus". In the meantime, the bigotry of western democratic regime and the political intentions of "exporting democracy" also play a role. Especially after the collapse of the Soviet Union, quite a number of scholars are confident about the "inevitable" collapse and democratic transition of the Chinese Communist Regime. Thus, some of them tend to study the imagined collapse from top to end due to struggle among Chinese elites. Besides, some others aim to find "mass disturbances" among grassroots of China in order to facilitate the "civil society" of democratic regime, and then reinforce their study of "other types of organizations". While the "linage or intermediary institutions", which maintain and improve current political system, are only regarded as the rule tool of the "core apparatus" with subtle significance, while its important role of representing the popular will as well as delivering social elites to CPC and government organizations is also neglected. Therefore, it's impossible for those scholars to identify the significant role played by the "linage or intermediary institutions" in the entire China's political ecology, which logically limits related study. For this, the writer calls on that experts and scholars of domestic politics circle should throw a lot of efforts to probe the huge enormous influence imposed on China's political ecology by the "linage or intermediary institutions". Many "linage or intermediary institutions", such as the Communist Youth League, serve as vital channels to select and cultivate political elites in China. In spite of that, few documents and even fewer empirical studies are involved in the approaches of the mentioned election, cultivation and 
delivery of cadres, as well as the characteristics of cadres developed through these approaches. This is indeed a research gap of Chinese politics.

\section{References}

Arendt, H. (2004). The origins of totalitarianism. Schocken Books. http://dx.doi.org/10.1215/9780822390169 $-017$

Barnett, D. (1960). Communist china and Asia: Challenge to American policy. Harper \& Brothers: Oxford University Press.

Bol, K. (1992). This culture of ours: Intellectual transitions in Tang and sung china. Stanford, Calif.: Stanford University Press.

Cheng, L., \& White, L. (1988). The thirteenth central committee of the Chinese communist party: From Mobilizers to managers. Asian Survey, 28(4), 371-399. http://dx.doi.org/10.2307/2644734

Dickson, B. (1997). Democratization in China and Taiwan: The adaptability of Leninist parties. Oxford University Press.

Dittmer, L., \& Liu, G. (2006). China's deep reform: Domestic politics in transition. Lanham, Md.: Rowman \& Littlefield Publishers.

Fairbank, K. (1979). The united states and china. Cambridge, Mass.: Harvard University Press.

Fairbank, K., \& Goldman, M. (1998). China: A new history. Cambridge, Mass: Belknap Press of Harvard University Press. http://dx.doi.org/10.4159/harvard.9780674333468

Goldstein, A. (1994). Trends in the study of political elites and institutions in the PRC. China Quarterly, 139, 714-730. http://dx.doi.org/10.1017/S0305741000043125

Huntington, S., \& Moore, H. (1970). Authoritarian politics in modern society: The dynamics of established one-party systems. New York: Basic Books.

Kou, J. (2010). Zhong gong jing ying zheng zhi de yan bian : Zhi du hua yu quan li zhuan yi, 1978-2010. Taibei Shi: Wu nan Press.

Lee, H. (1991). From revolutionary cadres to party technocrats in socialist china. Berkeley: University of California Press.

Lee, Y. (1983). China's 12th central committee: Rehabilitated cadres and technocrats. Asian Survey, 23(6), 673-691. http://dx.doi.org/10.1525/as.1983.23.6.01p00553

Lewis, J. (1963). Leadership in Communist china. Cornell University Press.

Li, C. (2001). China's leaders: The new generation (p. 27). Lanham Rowman \& Littlefield Publishers.

Li, C. (2005). Hu's Policy Shift and the Tuanpai's Coming-of-Age. In China Leadership Monitor (p. 15, pp. $1-16)$.

Li, C. (2008). China's changing political landscape prospects for democracy (pp. 98-117). Washington: Brooking Institution Press.

Li, C. (2009). The Chinese communist party: recruiting and controlling the new elites. Journal of Current Chinese Affairs, 38(3), 13-33.

Li, C., \& White, L. (1998a). The Thirteenth Central Committee of the Chinese Communist Party: From Mobilizers to Managers". Asian Survey, 28(4), 371-399. http://dx.doi.org/10.2307/2644734

Li, C., \& White, L. (1998b). The fifteenth central committee of the Chinese communist party: Full-fledged technocratic leadership with partial control by Jiang Zemin. Asian Survey, 38(3), 231-264. http://dx.doi.org/10.2307/2645427

Meyer, A. (1983). Communism and leadership. Studies in Comparative Communism, 16(3), 165-169. http://dx.doi.org/10.1016/0039-3592(83)90002-9

Nathan, A. (2003). Authoritarian resilience. Journal of Democracy, 14(1), 6-17. http://dx.doi.org/10.1353/ jod.2003.0019

Oksenberg, M. (2002). China's political system: Challenges of the twenty-first century. In J. Unger (Ed.), The Nature of Chinese Politics. New York, M. E. Sharpe. http://dx.doi.org/10.2307/3182364

Pei, M. (2006). China's trapped transition the limits of developmental autocracy. Harvard Press. 
Pye, L. (1968). The spirit of Chinese politics: A Psychocultural study of the authority crisis in political development. Cambridge Mass: M.I.T. Press.

Schurmann, F. (1966). Ideology and organization in communist China. Cambridge University Press.

Shambaugh, D. (2008). China's Communist party atrophy and adaptation. Calif: Woodrow Wilson Centre Press University of California Press.

Shirk, S. (2007). China: Fragile superpower. Oxford: Oxford University Press.

Tsou, T. (1986). The Cultural Revolution and post-Mao reforms: A historical perspective. Chicago: University of Chicago Press.

Walker, L. (1955). China under communism: The first five years. Yale University Press.

Womack, B. (1991). Contemporary Chinese politics in historical perspective. Cambridge: Cambridge University Press.

Yang, D. (2003). State capacity on the rebound. Journal of Democracy, 14(1), 43-50. http://dx.doi.org/10.1353/ jod.2003.0024

Zang, X. (1993). The fourteenth central committee of the CCP: Technocracy or political technocracy? Asian Survey Asian Survey, 33(8), 787-803. http://dx.doi.org/10.2307/2645088

Zang, X. (2004). Elite dualism and leadership selection in china. London; New York: Routledge Curzon.

Zheng, Y. (2011). Gai ge ji qi di ren = the reform and its enemies. Hangzhou Shi: Zhejiang Press.

\section{Notes}

Note 1. Martin Jacques, Understanding the rise of China, FILMED OCT 2010, POSTED JAN 2011, TEDSalon London 2010, accessed at: http://www.ted.com/talks/martin_jacques_understanding_the_rise_of_china.html

Note 2. Yongnian Zheng, Zaobao, Jan. 27th, 2004.

Note 3. There were five general secretaries from Joseph Stalin era to the collapse of the Soviet Union as Nikita Khrushchev, Leonid Brezhnev, Yuri Andropov, Konstantin Chernenko and Mikhail Gorbachev. The four leaders, except Mikhail Gorbachev, are all struggle in the same generation with bloodying cleaning to the previous leader. When the younger Gorbachev tried to reform the political system, the Soviet Union collapsed instantly.

Note 4. Wukan Event is the villager's riot against local government. However, the CCP adapted enlightened and tolerant approach instead of former repressive way to handle this riot. And at last, villages' legitimate demands received government and the CCP's focus, and the rebellious movement transformed to a peaceful Interest expression. Detail please see: Website of Duowei, access at: http://china.dwnews.com/big5/news/2012-04-17/ 58706588.html

Note 5. Roderick MacFarquhar, Debate between Roderick MacFarquhar and Andrew Nathan in "Is Communist Party Rule Sustainable in China "in Reforming China Policy: The Carnegie Debates, Library of Congress, October 5th 2006, accessed at: http://carnegieendowment.org/files/cds_macfarquhar.pdf.; Richard Baum, “China's Road to 'Soft Authoritarian' Reform”, U.S.-China Relations and China's Integration with the World, Aspen Institute, 19, no. 1 (2004), pp.15-20;

Note 6. Zhang Weiwei, Meritocracy vs. Democracy, The New York Times, 09,November, 2012, Accessed at: http://www.nytimes.com/2012/11/10/opinion/meritocracy-versus-democracy.html?pagewanted=all

Note 7. This policy was advocated by Deng Xiaoping and first appeared in "Resolutions for Certain Historical Issues of the Party Since the Establishment of the P.R.C" and was formally written into the Constitution of the CCP in it 12th National Congress. Detail please see: "Cadre Four Modernization" Criteria, website of the CCP, accessed at: http://dangshi.people.com.cn/GB/165617/173273/10415244.html

Note 8. According to Cheng Li's definition, 'Technocrat' means the political leaders who have experienced the college training of Engineer and science, and also have engaged in relevant profession of engineer or science. Detail please see: Cheng Li, China's Leaders: The New Generation(Lanham, Maryland: Rowman \& Littlefield Published), 2001, p. 27.

\section{Biographical Notes}

Yunzhe CHEN is a PhD Candidate in the School of Humanity and Social Science at the University of New South Wales. He is also the contact research of the Central School of the Communist Youth League of China. 
His Specialty is China's leadership politics and the Communist Youth League of China. Address: School of Humanity and Social Science, Building 28, University of New South Wales (Canberra), Canberra, MO, +61 2 6268 8867, Australia [Yunzhe.chen@student.adfa.edu.au].

\section{Copyrights}

Copyright for this article is retained by the author(s), with first publication rights granted to the journal.

This is an open-access article distributed under the terms and conditions of the Creative Commons Attribution license (http://creativecommons.org/licenses/by/3.0/). 